\title{
A Comparative Study of Cross-cultural Gratitude Strategies among Hausa, the Case of Arab and Chinese Students
}

\author{
Hassan Isyaku (Corresponding Author) \\ Department of English, Faculty of Modern Languages and Communications, University Putra Malaysia, 43400 Serdang, Selangor Malaysia \\ E-mail: Hassan.isyaku@yahoo.com
}

Ma Yuepeng

Department of English, Faculty of Modern Languages and Communications, University Putra Malaysia, Malaysia 43400 Serdang, Selangor Malaysia E-mail: amandacai0329@gmail.com

Qusay Mahdi

Department of English, Faculty of Modern Languages and Communications, University Putra Malaysia, 43400 Serdang, Selangor Malaysia E-mail:1m3qusay@gmail.com

Gassan Sarhan

Department of English, Faculty of Modern Languages and Communications, University Putra Malaysia, 43400 Serdang, Selangor Malaysia E-mail: ghasaansarhan@yahoo.com

Nahid Salih

Department of English, Faculty of Modern Languages and Communications, University Putra Malaysia, 43400 Serdang, Selangor Malaysia E-mail: abdokoubas@gmail.com

Shamala Paramasivan

Department of English, Faculty of Modern Languages and Communications, University Putra Malaysia, 43400 Serdang, Selangor Malaysia E-mail: shamala@upm.edu.my

Doi:10.7575/aiac.alls.v.7n.6p.137

Received: 11/08/2016

URL: http://dx.doi.org/10.7575/aiac.alls.v.7n.6p.137

Accepted: 25/10/2016

\begin{abstract}
The research investigated the thanking/gratitude strategies of three distinct cultures; Hausa, Chinese and Arabic languages with the aim of finding out the different strategies used by them and how different they are in their use of such strategies. The study employs Cheng (2005) Taxonomy of gratitude strategies in analyzing the data which was obtained from 15 participants among the Hausa, Chinese and Arabic students in UPM through the use of DCT (discourse completion Task) which were translated by the researchers into the three languages respectively before retranslated in to English language for analysis. The findings show a significant relationship in the use of "Simple Thanking strategy" among the three cultures as this strategy is utilized in $\mathbf{7 1 . 6 0 \%}$ of the responses in the Hausa version of the DCT, 62\% of the Arabian responses in the Arabic version of their DCT and 63.75\% of the responses in the Chinese version of the DCT and were all found to be in the "thanking alone and thanking followed by the favor strategies" consistently. While the least used strategy is the "recognition of imposition" which was only realized by Arabian students and none was found among the Hausa and the Chinese students.
\end{abstract}

Keywords: Cross-cultural, gratitude, discourse completion task, taxonomy

\section{Introduction}

According to Crystal (1999) "Pragmatics is the study of language from the point of view of the user especially of the choices they make, the constraint they encounter in using language in social interaction and the effects of their use of language on other participants in the act of communication" As an aspect of Pragmatics, speech acts can be seen as one of the most fundamental in the study of pragmatics and discourse analysis in general. For that fact, Searle (1976) see it as "a basic unit of discourse analysis" just like the sentences and other linguistic units are to the grammar. Austin (1962) defines speech act "as actions performed by saying something".

Man in his desire to express himself in the real world does not merely make utterances with any grammatical or lexical functions but also makes some acts through the utterances. E.g. the act of saying: 
“thank you, apologizing refusing or complaining" According to Bodman and Eisenstien (1988), the strategies of saying "thank you" is not onlydifficult to the second language users of the language but also to the native speakers with eachemploying his/ her peculiar strategies when saying "thank you" depending on the situation.

This study will examine and compare the thanking strategies used by the Hausa, Chinese and Arabian students in UPM. The data for the study is going to be collected using DCT (discourse completion Task) which the students will complete. In order to compare the participants' "thanking strategies", the participants will complete the same version of DCT questionnaire adopted from Bodman and Eisenstein (1988) which will be translated into the different languages of the participants and later in to English for the analysis.

There have been quite a number of weaknesses in relation to the use of the DCT and one among which is that, the data obtained from DCT is unnatural and it does not capture the true responsive situation of the participants. As far as the study is concern, the use of DCT is considered as most suitable as it simplifies the task of the researchers (The task of observing the natural occurrences of such strategies in a natural situation) and also it saves time and cost. Therefore, the data elicited from such way will be consistent with the naturally occurring data in most aspects or situations.

\subsection{Research Objectives}

The aims of the study are:

1. To investigate and analyze the thanking/gratitude strategies used by Nigerian, Chinese and Iraqi students in UPM.

2. To examine if Nigerians, Chinese and Arabians differ in expressing gratitude to people of different ages.

\subsection{Research Questions}

1. What are the common thanking/gratitude expressions used by Nigerian, Chinese and Iraqi male and female speakers?

2. How do Nigerian, Chinese and Iraqi speakers differ in expressing thanks/gratitude to their age-peers, old men and young subordinates?

\section{Methodology}

\subsection{Participants}

This research will use $\mathbf{1 5}$ participants 5 from Hausa (a Nigerian tribe considered the most populous in the country and here in UPM), 5 from Chinese (from china and not Malaysian Chinese but living in Malaysia) and 5 from Iraqis (who are also living in Malaysia) Their ages can range from 18-60 because our study will see whether age is a determining factor in using some thanking strategies. (Among the 5 participants for each language, 3 males and 2 females will be employed with each participant given a number identification).

\subsection{Instrument of data collection}

This research will use DCT (discourse completion test) which the participants will be asked to complete some open ended questionnaires which will be adopted from a modified version of DCT designed by Eisenstein and Bodman (1993) the questionnaires will be translated in to the three languages in question into Hausa, Chinese and Arabic before issuing to the participants. The reason for the translation is to get an objective data that is unaffected by the second language influence. The questionnaire will be modified to contain sixteen separate question-paragraphs describing various situations that are close to reality. The participants will be asked to give their responses for each situation described in the blank space that is going to be provided to them after every scenario question. These sixteen scenarios varied on the contextual factors of interlocutor's familiarity, social status, gender and age. After the data is collected, the data will be translated back to English for the analysis.

\subsection{Data Analysis}

This study will adopt Cheng's (2005) strategies of thanking and gratitude. After the data is collected, it will be identified, interpreted and explained based on the 8 thanking/ gratitude taxonomies adopted from Cheng (2005). The data will further be analyzed using descriptive statistics for a frequency count.

\subsection{Sampling}

Quota sampling technique will be adopted in selecting the population for the study. This sampling technique suggests that only a portion of the population that fulfills certain requirements or features will be selected to serve as the representative of the whole larger population (Black 1999) in this study, the researchers intend to use the postgraduate/ undergraduate students of University Putra Malaysia for sourcing the data.

\section{The Context of the Study}

In order to place the work in its relevant context, the researchers adopted Hyme's SPEAKING model which according to Inayah (2009) can be applied to different types of discourses. Hymes categorizes the sixteen components of different types of discursive contexts into an Acronym of S P E A K I N G which include: message form, message content, setting, scene, speaker/ sender, addresser, hearer, receiver, audience, addressee, purpose (outcomes), purpose goals, (key channels) form of speech, norms of interaction, norms of interpretation and genre. 


\section{Analysis of the Written DCT and The Study}

\subsection{Setting}

The setting or scene according to Hymes (1971) is the time,place and psychological setting of a conversation. The time when the study was conducted was during the period of one week, but the application of the DCT to the participants and the collection of it by the researchers were in a period of one day. For the place setting, the study was conducted in a laboratory situation, where the participants were given the DCT questionnaires to respond in convenient places such as the library and the graduate students study room which are all within the larger setting of the University and Malaysia. Psychologically, the participants assume themselves as the major agents of different situations within the DCT and as such, they find themselves in the houses, on the bus, or in a shopping store etc.

\subsection{Participants}

The participants here include both the researchers and the respondents or listeners. Five researchers took part in the present study, among them are: one Nigerian, a Chinese, and three Arabians. On the other hand, 15 participants are chosen from the three languages of the participants to take part in the study.

\subsection{Ends}

The ends which are purposes or the desired expected outcomes of the study are: To analyze the thanking strategies used by Nigerian, Chinese and Arabian Students and to also compare if they differ in expressing gratitude to their male and female counterparts. Or to the interlocutors of different ages (e.g. the Old and the young)

\subsection{Act}

The act here is the form and order of the event. First, the participants were issued with a 3-page DCT in their native languages. The DCT includes the instruction, background information and paragraphs of 16 situational questions which require the participants to place themselves in the different situations and answer the questions. The respondents were given enough time to fill in their responses. In that process, they made use of many illocutionary speech acts of gratitude/ thanking and locutionary acts which are the statements they used. And as the DCT prompts the participants to write their own responses, the perlocutionary act was also used.

\section{$3.5 \mathrm{Key}$}

It is the overall manner of speech, the mood or the spirit of the discourse according to Hymes (1971). The discourse that prompted the participant's responses was in some way semi-formal and neither in a serious mood or spirit nor in jocular spirit. It gives them a "light and open feeling" by placing the participants in everyday normal situation.

\subsection{Instrument}

It is the form and style of the speech. The form and style of this discourse is "written and face-to face" as the researchers were there to assist the participants. Therefore, the written Hausa, Arabic and Chinese DCTs are the main instruments available.

\subsection{Norm}

The rule governing this study was for the respondents to read each situation and place themselves in each situation which will afterwards warrant them to answer some questions using gratitude strategies they deemed fit for the situation. Similarly, the researchers did not lead or give the responses to their participants and so they maintain the rule of only talking when asked to do so by the respondents.

\subsection{Genre}

Because the research is a cross-cultural pragmatic study, the genre used was predominantly a written informal traditional genre of gratitude among different cultures which according to Hymes (1971) is transcribed or written in different genre. Generally, it belongs to the genre of pragmatic tests (Testing).

\section{Data Analysis}

\subsection{Framework of Data Analysis}

Table 1. Theoretical framework [Cheng's (2005) taxonomy for 8 strategies of expressing gratitude]

\section{STRATEGIES}

1) Thanking

\section{FEATURES}

A. simple thanking by only using the word "thank you"

B. thanking by stating the favor (thank you for your help, and thank you for your notice exemplify this substrategy)

C. thanking and mentioning the imposition caused by the favor (Thank you for helping me cleaning the room)

\section{2) Appreciation}

A. using the word "appreciate" (e.g. I appreciate it!) B. using the word "appreciate" and mentioning the imposition caused by the favor (e.g. I appreciate the time you spent for me) 
3) Repayment $\quad$ A. offering services, food... (next time is my turn)

B. feeling indebted (I owe you one)

C. promising future self-improvement (it won't happen again)

4) Recognition of imposition

4) Recognition of imposition

5) Apology
A. by acknowledging the imposition (exemplified by statements such as I know you are not allowed to give me extra time) B. stating or diminishing the need for the favor (you shouldn't do that)
A using the apologizer words ( $I$ am sorry)
B. using apology by stating the favor (I am sorry for the problem I made)
C. expressing embarrassment (I feel embarrassed)
D. criticizing oneself (I am such a fool...)

A. expressing positive reaction to a person (You are a life saver) B. expressing positive feeling to action (such as This book was really helpful)

7) Other are categorized as other Strategies. There are four subcategories under the other strategy:

A. here statement (e.g. Here you are!)

B. small talk (e.g. Your face is very familiar to me but I can't remember where I saw you. What do you study?)

C. leave-taking (e.g. Have a nice day!)

D. joking (e.g. Don't forget to pay again next time)

\section{8) Attention getter}

In the thanking situations, attention getter and address term are likely to occur in the same utterance. The alerters include:
A. Attention getter (e.g. Hey, Hi, Well)
B. Title (e.g. Dr., Professor! Sir!)
C. Name (e.g. John, Mary)

\section{The Thanking strategies Among Hausa Students of UPM}

\subsection{Thanking Alone}

\section{Thanking Alone}

$\mathbf{2 8}$ responses made by the participants portray "thanking alone" strategy. They use "thank you” alone in situations where the favor done is very little and usual.

E.g. Nagode Thank you

\section{Thanking by stating the favor done/ Moral attachment}

$\mathbf{9 0 \%}$ of the Hausa speakers are predominantly Muslims. Out of the 30 responses of the participants using this strategy, 17 tend to attach strong moral religious values after saying thank you. E.g.

Nagode, Allah ya saka da alkhairi Thank you, may god shower on you his blessings.

While 13 responses were made stating the favour done after the use of "Thank You”

e.g. Nagode dayimin taimakonnan Thank you for helping me.

\subsection{Appreciation}

\section{Using the word appreciate alone}

None of the participants used the word "I appreciate alone", and this is because according to the culture, it sounds impolite and ungrateful to the other party.

\section{Using the word "appreciate" and mentioning the imposition caused by the favor $\square$}

Nayi murna kwarai, dajin haka kuma nagode I really appreciate for hearing this and thank you 


\subsection{REPAYMENT}

\section{Feeling Indebted}

Only 1 participant made use of this thanking strategy in his response. Only participant No. 3 made use of this strategy when he was offered a loan of $\$ 500$ by his friend. E.g.

Nagode, zan biyaka da izinin ubangiji Thank you, I will pay you by Allah's will

\section{Promising Future Self-improvement}

Here, only participant No.3 made use of future self-improvement when being added salary. E.g.

Naji dadi kwarai, zan kara zage damtse I appreciate it, I will add more effort.

\subsection{Recognition Oof Imposition}

None of the respondents used this strategy.

\subsection{Apology}

\section{Using Apology by stating the Favor}

Only participant no.1 made use of this strategy in one response and this is because Hausa culture doesn't use apology so often where a favor is made. E.g

Nagode, kayi hakuri da wannan wahalar dana sakaka aciki Thank you, I am sorry for putting you through this.

\section{Expressing Embarrassment}

Participant no.2 decided not to say thank you to the elderly driver as he said:

He was embarrassed for showing his impatience (naji kunyane na nuna rashin hakuri na)

\subsection{Positive Feelings}

\section{Expressing Positive Feeling}

Participant no. 3 and no. 2 made use of this strategy in their five responses towards the favor done to them. E.g Da kyau, aikinka yayi kyau kwarai that's good, your work is awesome

\subsection{Others}

\section{Leave taking}

Among the strategies for expressing "thank you" here, only the Leave taking strategies are used by participant no 2. And no.4 in 3 responses, this according to the Hausa culture shows that the participants are not attached personally to the interlocutors. e.g., in the shopping stores, when he was about to leave, participant no. 2 said this to the salesman. E.g. sai anjima later

\subsection{Attention Getter}

5 responses by three participants used five exclamatory attention getters. Participant no. 2, after returning from work and finding the house clean made use of an attention getter. E.g

Kai! Abu yayi kyau, Allah yasaka Wow! Everything looks good, may god bless.

Table 2. Frequency and percentage of overall strategy use among Hausa students

\begin{tabular}{lll}
\hline Strategy & Number & percentage \\
\hline Thanking & 58 & $71.60 \%$ \\
\hline Appreciation & 6 & $7.41 \%$ \\
\hline Repayment & 2 & $2.47 \%$ \\
\hline Apology & 2 & $2.47 \%$ \\
\hline positive feeling & 5 & $6.17 \%$ \\
\hline Attention getter & 5 & $6.17 \%$ \\
\hline Other & 3 & $3.70 \%$ \\
\hline
\end{tabular}




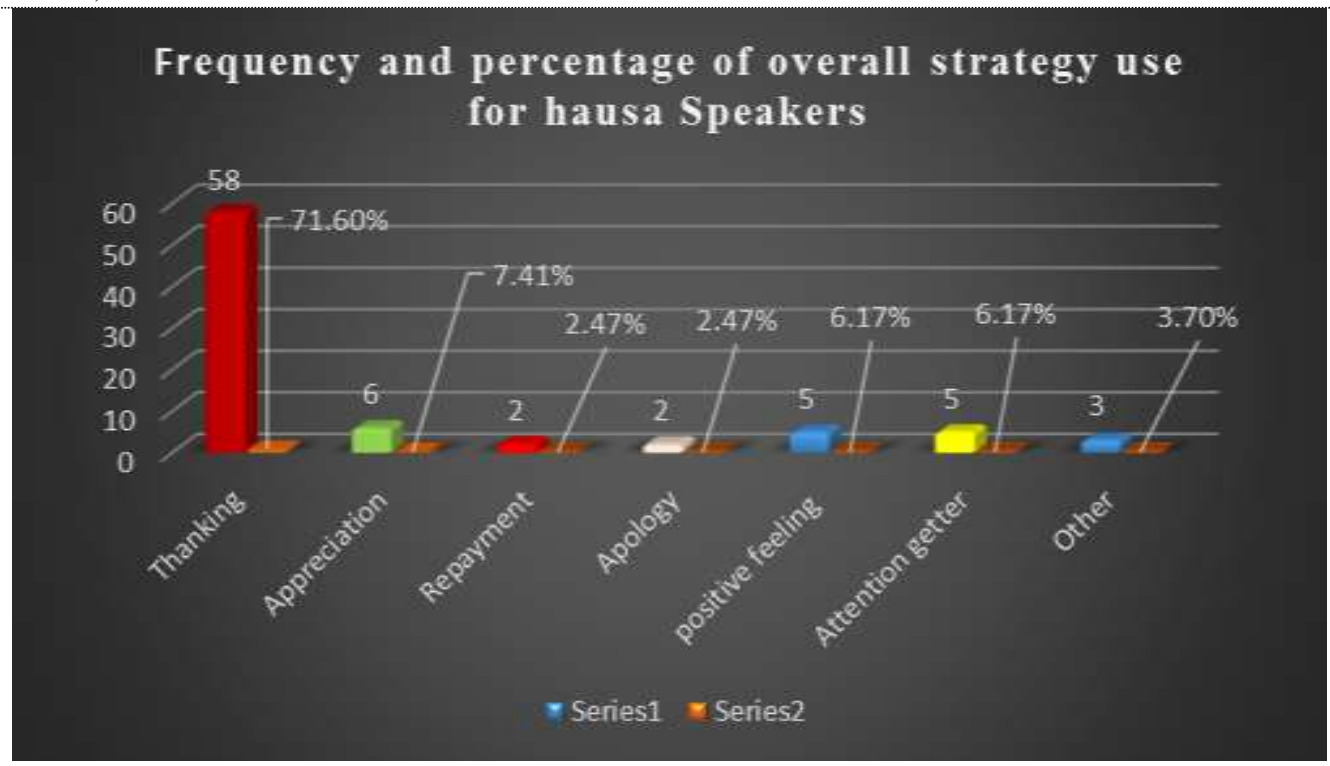

Chart 1. Frequency and percentage of overall strategy use among the Hausa participants

\subsection{Conclusion}

From the table above, one can fathom that the most used gratitude strategy is the "thanking strategy" with $\mathbf{7 1 \%}$ of the participant's responses including it, followed by Appreciation which is close to saying "thank you" in Hausa with 7.41\%. The next most used strategy according to the data is "Expressing positive feeling" with 6.17\% next after that is the use of "attention getters" within another structure with 6.17\%. Finally, "repayment" and "Apology" strategy for gratitude are the least used strategies among the Hausa Graduate students of UPM with only $2.47 \%$ each.

\section{The Thanking Strategies among Arabian Students of UPM}

\subsection{Thanking Strategy}

\section{a) Thanking alone}

Since "thanking alone" strategy comprises utterances made up of thanking words such as 'thank you' or 'thanks'. There were $\mathbf{3 2}$ that were made using thanking alone strategy among the participants.

E.g. 'Shukran' thank you

\section{b) Thanking by stating the favor done}

Out of (50) thanking responses. 18 responses have been utilized to display thanking and stating the Favor as a strategy to express gratitude.

E.g. Shukran li ahtimamk, ant falan sadiq wafi

$$
\text { Thanks for your interest; you are absolutely a best friend. }
$$

\subsection{Appreciation}

\section{a) Using the word "appreciate alone"}

Only one of the participants used this strategy, since using the word appreciate alone doesn't bear a heavy gratitude in its meaning.

\section{E.g. Ana oqder laka ha`a I appreciate it}

\section{b) Using the word "appreciate" and mentioning the imposition caused by the favor}

Four participants in their responses employed the word "appreciate" and mentioning the imposition caused by the favor. This reveals to what extend that the people used to utilize such expressions among them.

E.g. Ana uqader hatha, hatha lotf mink, atmnh lak al najah aldaeem fi hayatok.

Appreciate it. That is so nice of you, I wish you all success in your life.

\subsection{Repayment}

\section{a) Offering or promising service}

Participants no. 5 and no. 1 have used this strategy in their responses towards the favor of Offering or promising service.

E.g. Ana aml an yakun dawri fi al mara al qadima, ba al faal ant tamtalk qalb kabeer.

I hope to turn it back to you at a nearest time. You absolutely have a good heart. 


\section{a) Acknowledging the imposition}

Only one participant "acknowledged the imposition" in his response to the action which expresses a kind of modesty I a given situation

E.g. ana uaked lak ina telka al ziyada fi ratbi stjaaalni akther mthabra.

I admit this increase in my salary will push me to be more persistent.

\subsection{Apology}

\section{Using Apology by stating the Favor}

This strategy was used by only one participant, although this strategy has a broader use in Arabic conversation. It could be attributed to the type of questions that is included in the DCT which elicits an apology strategy.

E.g. lakad ahsant al ammal, ana jidaa usef li adm musaadatak.

You did a great job and I am sorry for not helping you.

\subsection{Positive Feelings}

\section{Expressing Positive Feeling}

Five Arab respondents made use of this strategy in framing 19 responses over the total no of 80 responses.

E.g. inaka tamaal besorah jayadah, hafeth ala thalek.

You are doing a great job, thank you my friend.

\subsection{Others}

None of the participants used this strategy.

\subsection{Attention Getter}

\section{a) Attention getter}

Only in two situations that two responses out of all responses demonstrated the use of "attention getter".

E.g. ma asedek saraha areed ahethnak alaa ali sawetah.

Wow! I really want to hug you for what you did, thank you so much.

Table 3. Frequency and percentage of overall strategy use among the Arabian participants

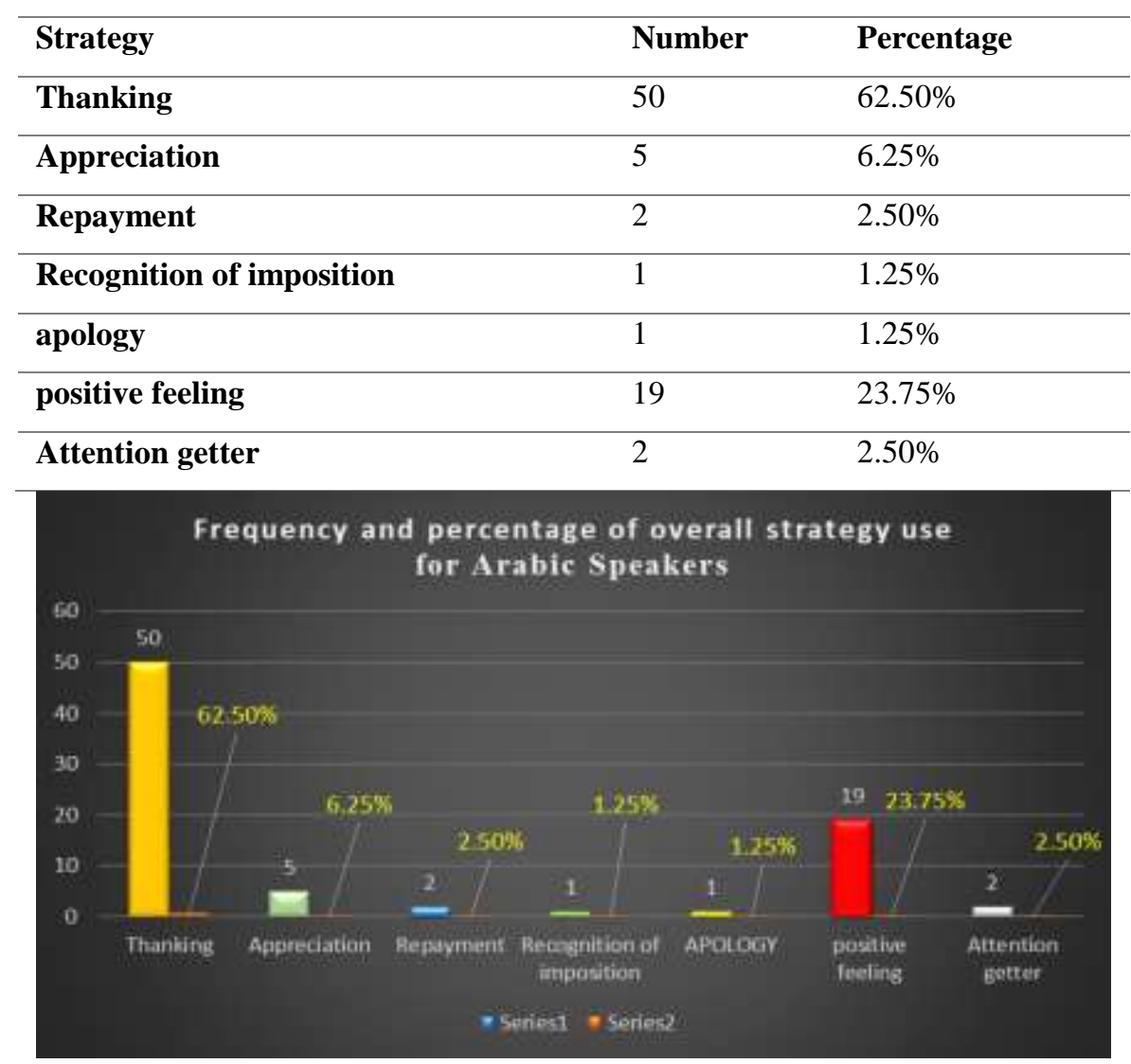

Chart 2. Frequency and percentage of overall strategy use among the Arabian participants 


\subsection{Conclusion}

Figure and Table illustrate that the thanking strategy with $(\mathbf{6 2 . 5 0 \%})$ is the most frequently used strategy. The second most commonly used strategy by the Arab participants was positive feeling with (23.75\%). Appreciation takes the third most frequently used strategy with the percentage of (6.25\%). The fourth most frequently used strategy with $(\mathbf{2 . 5 0 \% )}$ is Attention getter. Finally, Arab speakers use of Repayment strategy is only (2.50\%), and Apology together with Recognition of imposition with only (1.25\%) consistently.

\section{The Thanking strategies Among Chinese speakers}

\subsection{Thanking Alone}

\section{Thanking Alone}

17 responses were found to include "thanking alone" strategy. They use of "thank you" alone is usually made based on the Chinese culture in situations where the favor done is very little and when they received messages from a common friend.

E.g. 谢谢你。 (Thank you in Chinese)

\section{Thanking by stating the favor done/ Moral attachment}

51 responses were made to include the favour done to the participants after the use of "Thank You". This tend to show the degree and extent to which they show how grateful they are. This usually comes before or after saying "Thank you"

E.g. 非常谢谢你，我真的很喜欢这个礼物。（Thank you very much, i really like this present）

\subsection{Appreciation}

\section{Using the word appreciate alone}

None of the participants used the word "I appreciate alone", and this is because Chinese people do not have the habit to use the word I appreciate alone.

\section{Using the word "appreciate" and mentioning the imposition caused by the favor}

6 participants made use of this strategy in their 6 responses. This shows the respect to the other person.

E.g. 非常感谢你, 你真的是帮了我大忙了。（I really appreciate it. You really helped me.)

\subsection{Repayment}

There are 17 responses that made use of repayment strategy. Among them, only 10 responses used repayment strategy to show "offering service".

E.g. 谢谢你，下次我请你吃饭。（Thank you . Next time is my turn to pay for dinner.）

The rest of 7 responses are "Promising Future Self-improvement" by using repayment strategy.

E.g. 谢谢你，我下次会做的很好。（Thank you. I will do even better next time. )

\subsection{Recognition of Imposition}

None of the respondents used this strategy.

\subsection{APOLOGY}

\section{Using Apology by stating the Favor}

Only participant no.5 made use of this strategy for once in responding to getting off the car.

对不起, 我想在这里下车。(Am sorry! I want to alight here.)

\section{Expressing Embarrassment}

Only Participant no.3 used the apology strategy instead of "thank you" to decrease embarrassment between him and his friend.

唉呀!不是说好了我做这部分家务的吗? 真的是麻烦你了。（Aya! I wanted to do that; $u$ should have let me do the housework at this time. It is really nice of you to help me. )

\subsection{POSITIVE FEELINGS}

\section{Expressing Positive Feeling}

Only Participant no.3 used this strategy for one time.

啊真是太感谢你了, 帮了我个大忙。（A！I really thank you. You really helped me a lot.) 


\subsection{Others}

\section{Small talk}

Only Participant no.3 using this strategy also for one time.

天呢, 你怎么会知道我想要这件毛衣, 你真的是太了解我了。( Oh My God. How do you know that i want this blue sweater? You really know me. )

\subsection{Attention Getter}

None of the respondents used this strategy.

Table 4. Frequency and percentage of overall strategy use among the Arabian participants

\begin{tabular}{lll}
\hline Strategy & Number & Percentage \\
\hline Thanking & 51 & $63.75 \%$ \\
\hline Appreciation & 6 & $7.5 \%$ \\
\hline Repayment & 17 & $21.25 \%$ \\
\hline Recognition of imposition & 0 & $0 \%$ \\
\hline apology & 1 & $1.25 \%$ \\
\hline positive feeling & 1 & $1.25 \%$ \\
\hline Other Small talk & 1 & $1.25 \%$ \\
\hline Attention getter & 0 & $0 \%$ \\
\hline
\end{tabular}

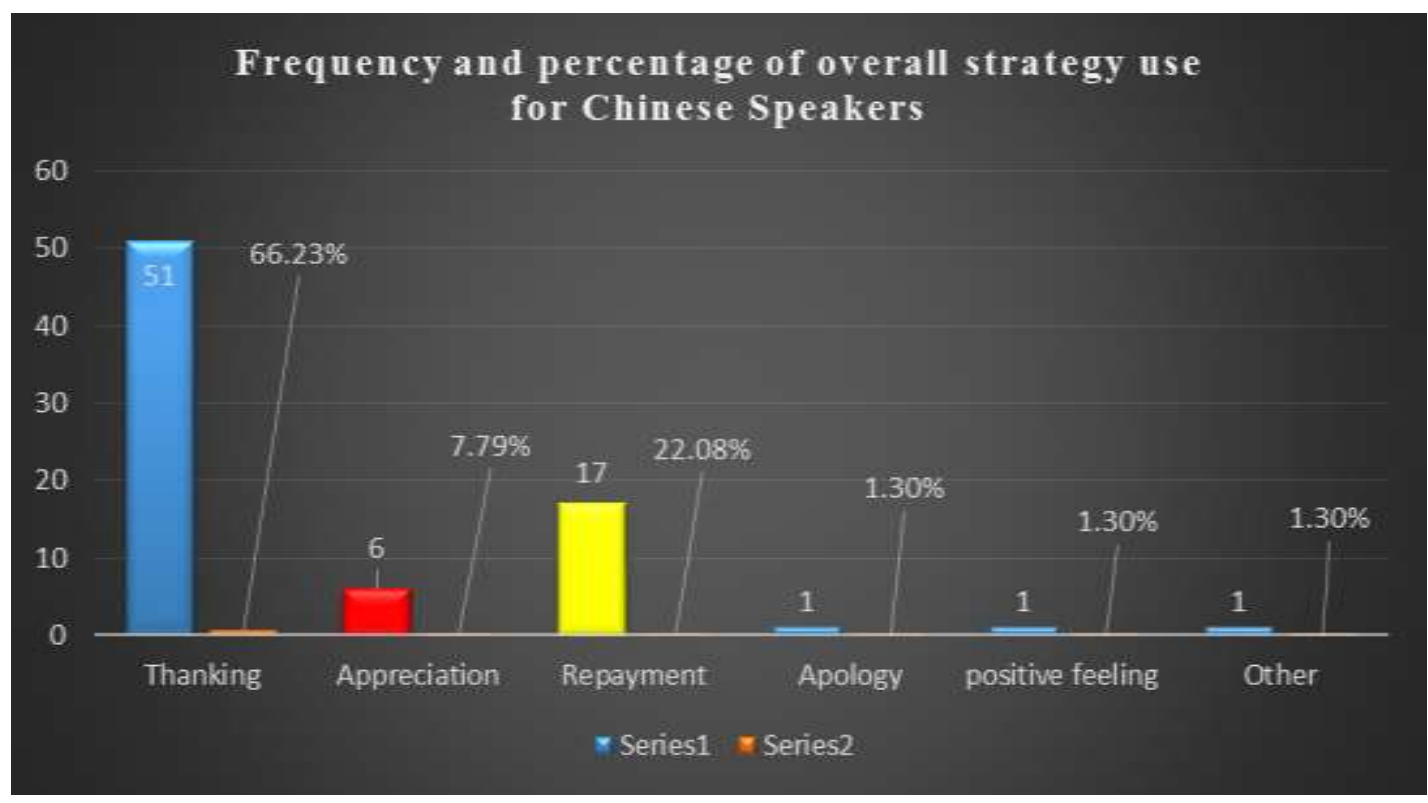

Chart 3. Frequency and percentage of overall strategy use among the Chinese participants

\subsection{Conclusion}

From the information above, we can conclude that the mostly used gratitude strategy is "thanking strategy" with $\mathbf{6 3 . 7 5 \%}$, followed by Repayment strategy with $\mathbf{2 1 . 2 5 \%}$. The next is "appreciation" strategy with $\mathbf{7 . 5 \%}$ which we can see all from the chart above. Among all the strategies, "apology", "positive feeling”, and "other" (small talk) are all realized with only $\mathbf{1 . 2 5 \%}$. Finally, both "recognition of imposition" and "attention getter" have $0 \%$. 


\section{Findings and Conclusion}

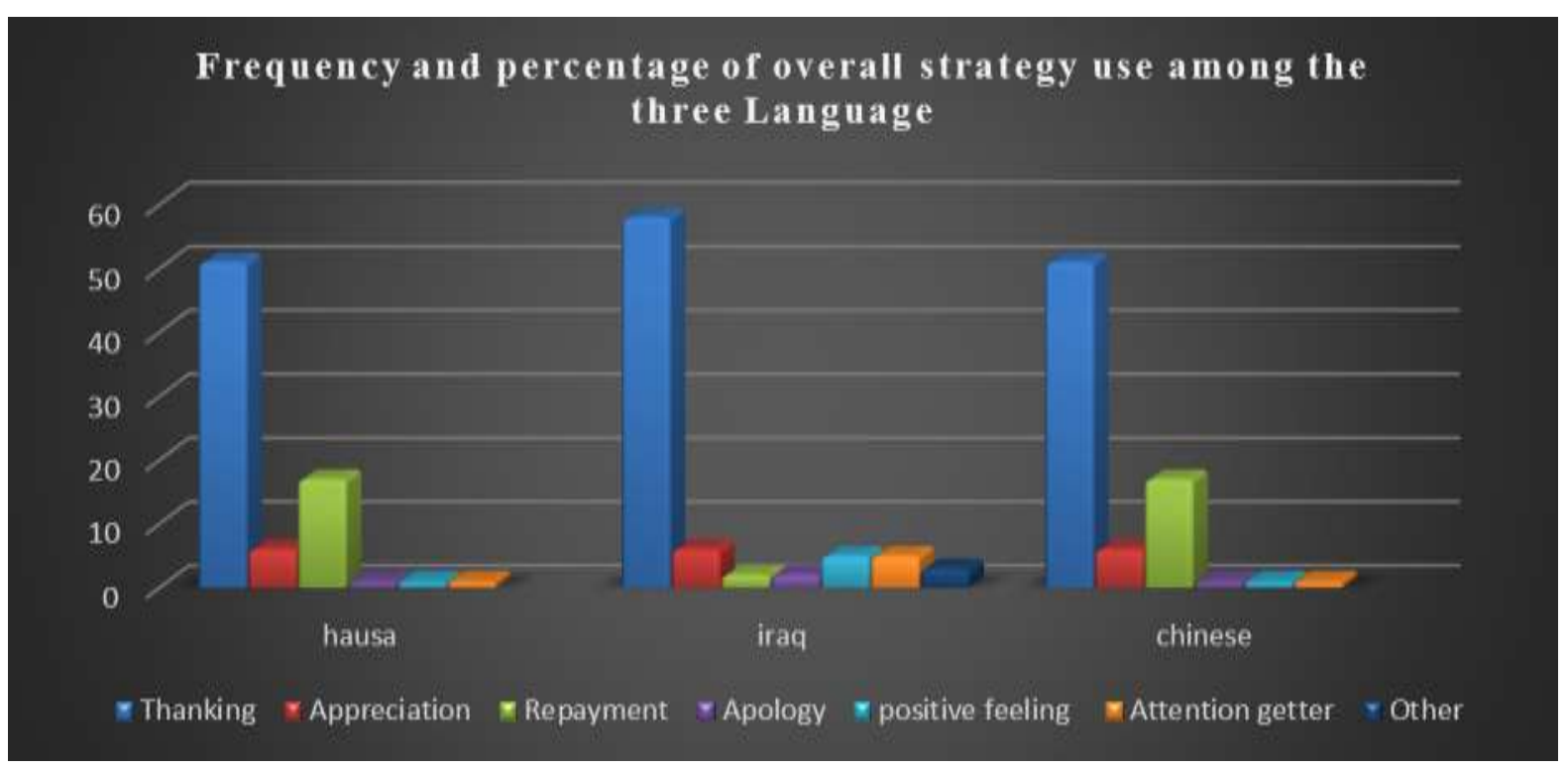

Chart 4. Frequency and percentage of overall strategy use among the three Language

It can be fathomed according to the findings that, there is a strong relationship between the three cultures (Hausa, Chinese and Arabic) in their use of "Simple Thanking" strategy as $\mathbf{7 1 . 6 0 \%}$ of the responses in the Hausa version of the DCT, $\mathbf{6 2 \%}$ of the Arabian responses in the Arabic version of their DCT and $\mathbf{6 3 . 7 5 \%}$ of the responses in the Chinese version of the DCT among the participants in UPM all were found to be in the "thanking alone and thanking followed by the favor strategies" consistently. This finding is in conformity with that of Fariba and Sanaz (2014) whose research in the use of thanking strategies among the Iranians shows $\mathbf{8 0 \%}$ of their intermediate subjects using "simple thanking" strategy in their English sample of their DCT.

For "Appreciation strategy", 7.41\% responses among the Hausa participants, $\mathbf{6 . 2 5 \%}$ responses among the Arabians and $\mathbf{7 . 5 \%}$ responses among the Chinese respondents have been made using "appreciation" strategy. This shows that in the use of appreciation strategy, there is no any significant difference between the three cultures.

However, in the use of "Repayment strategy", a significant difference was seen between the responses of the Chinese participants which was $\mathbf{2 1 . 2 5 \%}$ and the other two cultures who only recorded $\mathbf{2 . 4 7 \%}$ for Hausa and $\mathbf{2 . 5 0 \%}$ for Arabic participants which made the researchers to conclude that there is a significant relation between the Hausa and Arabic cultures in their use of "repayment strategy".

Only $\mathbf{2 . 4 7 \%}$ responses use “apology strategy" for Hausa, 1.25\% among the Arabian and the Chinese responses consistently. This indicates that there is also a strong correlation among the two cultures in the use of "apology strategy".

There wasn't any use of "recognition of imposition" strategy among the Hausa and Chinese culture while Arabic only recorded $1.25 \%$ use.

For "Positive feeling" strategy, 6.17\% among the responses in the Hausa version of the DCT made use of this strategy while Chinese recorded only $\mathbf{1 . 2 5 \%}$ but Arabic recorded up to $\mathbf{2 3 . 7 5 \%}$ making a significant difference between their use of "positive feelings" as compared to Hausa and Chinese.

Finally, in their use of "other strategies" only 3.70\% of the responses were recorded in the Hausa version of the DCT while $2.5 \%$ was recorded in the Arabic Version and $0 \%$ in the Chinese version of the DCT

\section{Conclusion}

One can conclude therefore that, the most frequently used strategy among the three cultures is the "simple thanking" and this is in conformity with several researches done in the same field. While the least used strategy is the "recognition of imposition" which was not found to be used in the Hausa and Chinese versions of the DCT and with only $1.25 \%$ in the Arabic version of the DCT. There is no any significant difference in the use of Gratitude strategies in addressing either females/males or young/old interlocutors among the three cultures.

\section{References}

Austin, J. L., \& Urmson, J. O. (1962). How to Do Things with Words. The William James Lectures Delivered at Harvard University in 1955.[Edited by James O. Urmson.]. Clarendon Press.

Black, T. R. (1999). Doing quantitative research in the social sciences: An integrated approach to research design, measurement and statistics. Sage. 
Cheng, S. W. (2005). An exploratory cross-sectional study of interlanguage pragmatic development of expressions of gratitude by Chinese learners of English. Unpublished PhD dissertations. The University of Iowa.

Eisenstein, M., \& Bodman, J. W. (1993). Expressing gratitude in American English. In G. K. S. Blum-Kulka (Ed.), Interlanguage pragmatics (pp. 64-81). New York: Oxford University Press

Farashaiyan, A., \& Hua, T. K. (2012). A cross-cultural comparative study of gratitude strategies between Iranian and Malaysian postgraduate students.Asian Social Science, 8(7), 139.

Flowerdew, J. (2012). Discourse in English language education. Routledge.

Hymes, D. H. (1972). On communicative competence. In B. Pride \& J. Holmes (Eds.), Sociolinguistics (pp.269-293). Harmondsworth: Penguin.

Inayah, K. A. (2009). About The Simple Conversation. Bandung.

Kasper, G., \& Blum-Kulka, S. (Eds.). (1993). Interlanguage Pragmatics. Oxford: Oxford

Searle, J. R. (1976). A classification of illocutionary acts. Language in society, 5(01), 1-23.

Sussex, R. (1999). DAVID CRYSTAL, English as a global language. Cambridge \& New York: Cambridge University Press, 1997. Pp. x, 150. Hb \$9.95. Language in Society, 28(01), 120-124.

Yoosefvand, A., \& Rasekh, A. E. (2014). Gender Differences in the Expression of Gratitude by Persian Speakers. Journal of Applied Linguistics and Language Research, 1(1), 100-117.

\section{APPENDIXES}

\section{ENGLISH DCT}

Sample of the DCT adopted from a modified version of DCT designed by Eisenstein and Bodman (1993)

\section{Dear participant,}

Thank you for participating in this survey. This study is intended to explore cross cultural speech

behavior. The information you provide below will be used for this study only and will remain confidential. In the following section, please fill in the blank spaces with the correct information.

\section{Background information:}

Name:

Nationality

Language

Faculty.....

Department.

Age.

Gender.

\section{Instruction}

You will find the following scenarios involve being placed in a situation where you may feel, to different degrees, obliged or grateful to someone who has done something for or requested of/from you. Please imagine yourself in each situation and respond accordingly based on your immediate reaction. If you feel that a specified situation does not warrant a response, please provide an explanation.

1. It is Friday. You look into your wallet and notice that you only have $\$ 2.00$. your good friend at work notices this and hears you say,' I'll have to go to the bank.' Your friend asks if you need money, and you say that you forgot to go to the bank. Your friend says, 'I have plenty. How much do you need?' You say, 'Could you lend me \$5.00? I'll pay you back on Monday.' Your friend says, 'Sure. Are you sure you don't need more than that?' You say you don't. Your friend gives you the $\$ 5.00$. (Your friend is a male)

You would say:

You would say nothing because:

2. You board a bus, pay your money and take a seat near the front of the bus. Just before you stop, you guess that the driver is not going to stop. You move to the front, and ask the driver to stop and he stops. (The driver is an old man) You would say:

You would say nothing because:

3. It is your birthday, and you're having a few people over for dinner. A friend brings you a present. You unwrap it and find a blue sweater that you wish to have. (Your friend is a female)

You would say:

You would say nothing because: 
4. You work for a large company, which is usually very busy. You send your manager a request for some days off. The vice-president of personnel calls you into his office. He tells you to sit down. You feel a little nervous, because you have only been working there for six months. The vice-president says, "You're doing a good job. In fact, we are so pleased with you that I am going to give you a raise". (Your boss is younger than you and a female)

You would say:

You would say nothing because:

Today is your birthday. $\mathrm{X}$ sends you a text, wishing you a happy birthday

5. In the supermarket, you ask the cashier to bag your groceries. He does this, and then turns to begin serving the next costumer. You pay and pick up your bags to leave. (The cashier is an old man)

You would say:

You would say nothing because:

6. At the table in a restaurant a friend says, you have something on your face.' You ask where. Your friend tells you. You rub your face and ask,' Is it off?' your friend says that it is. (your friend is young and male)

You would say:

You would say nothing because:

7. You find yourself in sudden need of money-- $\$ 500$. You mention this to a friend. Your friend immediately offers to lend it to you. At first you say, 'Oh no, I didn't mean it as a request. I couldn't take it.' Your friend says,' really, it's all right. What are friends for?' Your friend insists again, and you take the check. (Your friend is a male)

You would say:

You would say nothing because

8. You are studying in another city. Both you and your roommate work. You come home late from work and find that your roommate has done some work around the house that you had promised to do, but had not had a chance to do.

(Your roommate is old and a male)

You would say:

You would say nothing because:

9. Your friend suggests going out to lunch. You say that you'd like to go, but you only have \$2. Your friend says. 'Ah, don't worry. I'll treat you today.' Your friend takes you to a very nice restaurant -a much more expensive one than you usually go to. You have a wonderful meal. Your friend pays, and you get up to leave.( Your friend is older and a female)

You would say:

You would say nothing because:

10. You have just gotten an admission from a foreign university. A close friend in the university tells you she has organized a farewell party for you.

You would say:

You would say nothing because:

11. You have just gotten your hair cut in a new style, and you like it better than the old one. Your friend sees it and you ask him what he thinks. He says, 'Hey, you've got a new haircut. It looks nice.'

You would say:

You would say nothing because:

12. You share an apartment with a friend. You're both sitting and relaxing in the living room. You ask your friend to hand you the newspaper which is nearby. Your friend gives you the newspaper. (Your friend is a male and younger)

You would say: Thanks.

You would say nothing because:

13. You enter a parking garage. As the parking attendant gives you the parking voucher, You hand him the money and ask him about the empty space. (He is middle age and older than you)

You would say:

You would say nothing because:

14. You have been invited to the home of a rather new friend. You have dinner with him and his family and a few other friends of theirs. The food was great, and you really enjoyed the evening. As you leave, your hosts accompany you to the door. (He is same as your age)

You would say:

You would say nothing because: 
15. Today is your birthday. $X$ sends you a text, wishing you a happy birthday. ( $\mathbf{X}$ is a male)

You would say:

You would say nothing because:

16. You have just got a job offering from a company. $X$ knows about it and $X$ congratulates you. ( $X$ is a female and younger)

You would say:

You would say nothing because:

\section{SAMPLE OF HAUSA DCT}

\section{Zuwaga mairubutun Amsoshi,}

Muna godiyar yarda dakayi kazamo/kizamo daya daga cikin masu taimakawa wajen yin wannan bincike na ilimi. Wannan binciken dai yana so ya gano dabi'un mutane ne a wajen jawabi-tamkar aiki a cikin al'adu daban daban wadanda suka shafi na Hausawa, yan kasar Sin da kuma larabawa.. Rahoton da zaka bayar zaa yi amfani da shine kadai ta wajen wannan binciken sannan muna masu tabbatar maka da cewa sirrinka bazai bankada ba. A cikin sashen da zai biyo baya, muna so kacike gurbin da aka bari da bayani na kwarai.

Bayani akan masu Amsa Tambayoyi

Suna: ..............................

Kasa:

Yare:

Fakolti.

Sashen

Fakolti.

Shekaru:

Jinsi:

\section{$\underline{\text { Umarni }}$}

Zaka sami kanka a cikin yanayi daban-daban a bisa ga tambayoyin da zasu biyo baya. Anaso kasaka kanka a cikin kowanne irin yanayi sannan ka amsa tambayoyin da suka shafi wannan yanayin yazamo idan kaine wani yamaka wani aiki, ko yabaka wani abu, ko ya tayaka murnar samun wani abu to tayaya zaka gode masa? kuma wanna irin kalmomi zakayi amfani dasu na godiya domin ka nunamasa cewa kagode? Idan kuma kana ganin abinda akayi maka watakila bai kamata kace kagode ba, to kafadi dalilin fadin hakan a kowanne irin yanayi. Kagane cewa amsa wadannan tambayoyi babu daidai ko kuskure a ciki. Saboda haka kasaki jikinka ka amsasu batare da wata tantama ba. 1. Yau ranar Jumma'a ce, kaduba aljuhunka kaga baka do komai sai dala biyu. Babban abokinka a wajen aiki da ya fahimci halin da kake ciki bayan yaji kace kanaso kajeka banki sai ya tambayeka ko kana son aron kudi a wajensa. Sai kai kuma kace kamanta bakaje banki ba amma yabaka aron dala biyar zaka biyashi a ranar Litinin. Sai yace "katabbata baka neman fiye da hakan?" sai kace/kikace "a’a" sai abokinka yadauko kudin yabaka. (kaddara abokink/ki namijine)

Zaka ce masa.

Baza kace komai ba saboda.

2. Kaddara bayan kashiga mota, ka biya kudin motar sannan kasamu wuri ka zauna. Gab da zuwa wajen da zaka sauka, sai kayi tsammanin cewa direban bazai tsaya ba. Sai kayi sauri kataho wajen dayake zaune kafada masa ya tsaya zaka sauka. Sai direban ya tsaya. (Direban tsohone)

Zakace masa:

Bazakace masa komai ba saboda:

3. Kaddara yau ranar haihuwarkace, ka gayyaci mutanen dabasu da yawa yin liyafa. Sai abokiyarka ta kawo maka kyauta a cikin takarda, bayan ka bude sai kaga wata rigar sanyi ce koriya mai kyau da kake ta muradin saya.

Zak ace mata.

Bazakace mata komai ba saboda

4. Kana yiwa wani babban kamfani aiki wanda hakan yasa baka samun lokacin kanka. Watarana, sai ka turawa manajan ka takardar neman hutu. Turawarka keda wuya sai mataimakiyar shugaban fama da matsalolin maaikata ta kiraka zuwa cikin ofishinta ta baka wuri tace kazauna. Bayan ka zauna sai tace "Nasan cewa a tsorace kake saboda watan ka shida 
kawai anan amma kana neman hutu ko? Sai taci gaba da cewa "lallai muna masu farinciki da irin aikin da kake yi mana a nan saboda haka nema nake maka bushara da munyi maka Karin albashinka"

Zakace mata.

Bazakace mata komai ba saboda

5. A cikin kasuwa bayan ka gama sayayya, sai kacewa mai karbar kudin ya saka maka duk abin daka saya a cikin jaka. Nan take ya saka maka komai sannan ya ci gaba da alamuransa. Sai kabiya shi kudinsa na kaya zaka tafi.

Zaka ce masa.

Bazaka ce komai ba saboda

6. A kan teburi a cikin otel, abokinka yace maka akwai wani abu akan fuskarka, sai kace "a ina?" sai yafada maka sannan ka goge kasake tambayar sa "yafita?” sai abokin ka yace maka eh! (Abokimnka yarone kamar ka)

Zakace masa

Baza kace masa komai ba saboda.

7. Kasamu kanka a cikin wani irin yana yi na rashin kudi kuma kana neman kudi har dala dari biyar. Sai kafada wa abokinka halin dakake ciki. Nan take yace zai baka aro. Da farko kace masa bawai kana nufin yabaka aro bane saboda haka bazaka karba ba amma sai abokinkan yace bakomai kakarba amfanin abokantakar kenan. Sanan bayan kun danyi jayayya sai ka karbi chek din kudin.

Zaka cemasa

Bazakace masa komai ba saboda.

8. Kasamu kanka kana karatu a wata kasa. Kai da abokin zaman dakinka dukkaninku kuna aiki a kasar. Bayan kadawo gida daga wajen aiki sai kaga abokin zamanka yayi wasu ayyuka da kace zakayi da jumawa amma baka samu damar yi ba (Abokin dakinka ya girme ka sosai)

Zakace masa

Bazaka ce masa komai ba saboda.

9. Abokiyarka ta kawo shawarin fita aci abincin rana. Sai kace mata zakaso kaje amma dala biyu ce kadai a aljihunka. Sai tace karka damu "zan biya mana na yau" sai ta kaiku wani kayataccen wajen cin abinci kuka ci kuka sha ga abincin da yafi wanda kake ci ada tsada. Bayan kunci kun more, abokiyarka ta biya kudin kuka tashi zaku tafi.

Zak ace mata.

Bazaka ce mata komai ba saboda.

10. Kasamu damar yin karatu a kasar turai. Abokiyarka ta kusa dakai takiraka tace maka ta hada maka gaggarumar liyafar ban kwana

Zaka ce mata.

Bazakace mata komai ba saboda.

11. Bayan kayi aski mai kyau an yi maka ado na fada a gani kayi kyau sosai, sai abokinka yagani sai katambayeshi ko yayi kyau sai yace "kayi sabon askine? Kai kayi kyau sosai"

Zakace masa.

Bazakace masa komai ba saboda:

12. Kuna zaune tare da abokin zamanka a gida. Kuna cikin hutawa a cikin falo sai kace masa ya miko maka jaridar datake kusa da shi. Bayan ya miko maka,(abokinka bai kaika shekaruba)

Zaka ce masa.

Bazakace masa komai ba saboda

13. Kashiga cikin babban garejin da ake ajiye motoci na kudi. Bayan mai lura da wajen ya baka tikitin ajiye motarka, sai kabashi kudinsa ka tambayeshi wajen da babu kowa saboda ka ajiye motarka. Sai ya nuna maka. (Mai lura da wajen ya grime ka) 


\section{Zaka ce masa:}

\section{Bazaka komai ba saboda:}

14. Abokinka da baku jima da haduwa ba ya gaiyace ka gidansu. Bayan kunci abinci da iyayenshi tare da wasu abokananshi. Abincin yayi maka dadi sosai gami da haka, kaji dadin wannan yammacin. Da katashi zaka tafi, abokinka ya rakoka har wajen bakin kofa (shekarunku daya da shi)

Zakace masa:

Bazakace komai ba saboda:

15. Yau ranar haihuwarka ce, sai $X$ ya/ta aiko maka sakon murnar ranar haihuwa. ( $\mathbf{X}$ namijine)

\section{Zakace masa}

Bazakace komai ba saboda

16. Bakajima da samun aiki a wani babban kamfani ba. $\mathrm{X}$ taji labari sai tayi maka murna. (X yarinya ce wacce ka girma sosai)

\section{Zakace mata.}

Bazaka ce komai ba saboda.

\section{ARABIC VERSION OF CTD}

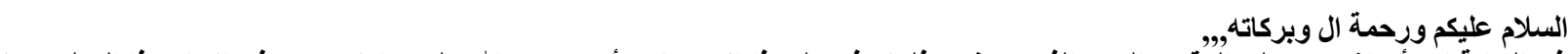

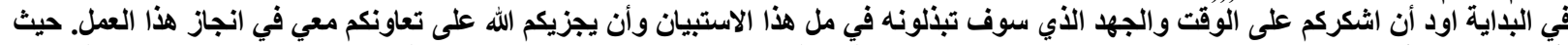

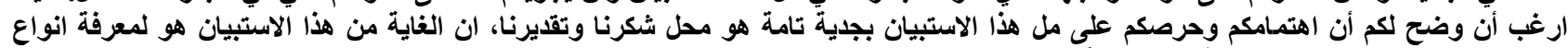
التعبير الخطابي المستخدم بين الثقافات المختلفة.

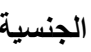

الكلية

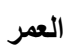

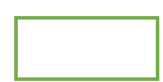

انثى

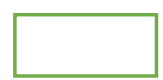
الاسم: اللغة القسم

في احد الايام و اثناء وقت العمل, فكرة في شراء شي ما, لكن عندما نظرت داخل المحفظة لم تجد سوى فكات قليلة وهي غير كافية للثر اءعر في تلك الكاء الاثناء

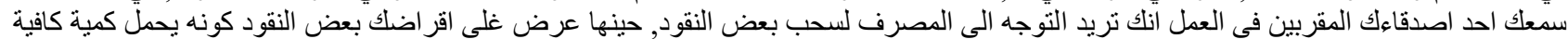

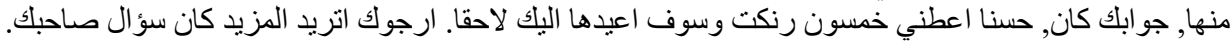
ما هو ردك كون صاحبك اقرضك خمسون رنكت؟ جران

احد الايام استقليت الباص, وبعد ان اعطيت نقود للجابي جلست في وسط الباص, لكن قبل ان يتوقف الباص في المكان المقصود انتابك شعور بان السائق لن يتوقف بالمحطة المقبلة, قتوجهت الى السيائق وطلبت منه التوقف في المحطة المقبلة.( السائف رجل كبير بلت بالسن)

$$
\text { ماهو جو ابك للسائق بعد التوقف؟ }
$$

في يوم عيد مبلادك, و اثناء الاحتفال تقدم احد الاصدقاء وقدم للك هدية. عند فتحك للهدية وجدة في داخلها قميص ازرق جميل جدا كنت نرغب بشر اءه منذ وقت.(صديقلك هو امراة) 
الموقف الرابع: - الم

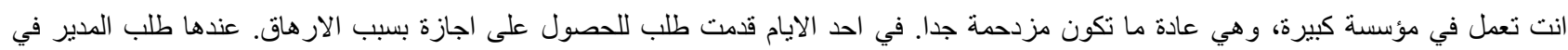

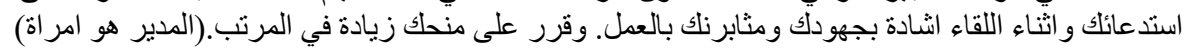

ماهو جو ابك لها؟

الموقف الخامس: عتد انتهائك من التبضع, طلبت من الكاشير ان يضع جميع اغر اضك في الاكياس, وبالفعل ثم وضع جميع الاشياء وتقديمها اليك بعد ان تم دفع الحساب. (الكاثشير رجل كبير بالسن).

ماهو جو ابك له؟

الموقف السادس: اثناء جلو سك في المطعم مع احد الاصدقاء, اشارة الى ان هنالك شي ما على جبينك. ثم انت سالته اين بالضبط فأجابك, وبعد ان مسحت وجهك جبدا سالته هل

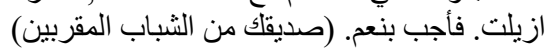

ماهو جو ابك له؟

الموقف السابع:

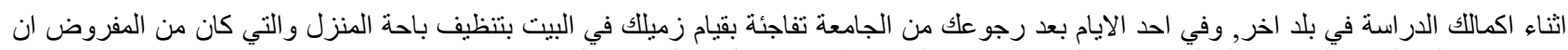

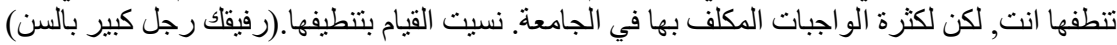

ماهو جو ابك له؟

الموقف الثامن: في احد الايام اقترح عليك زميلك في العمل بتناول الغداء في احد المطاعم. انت كنت نر غب بالذهاب الذاب معه لكنابك لاتملك سوى بعض الفكات, اجابك بعدم الاكتر اث للموضوع و النه سيدفع الحساب عنك, بالفعل اصطحبك الى احد المطاعم الفاخرة وبعد تناول الغداء دفع الحساب.(زميلك امر اة كبيرة بالسن)

ماهو جو ابك لها؟

الموقف التاسع:

كنت قد حصلت للتو على قبول من إحدى الجامعات الأجنبية . فقرر احد اصدقاءك المقربين على تنظيم حفلة وداع للك.

ماهو جو ابك له؟

الموقف العاشر:

بسبب تسريحت شعرك التقليدية, قدت بتغير التسريحة الى شكل اكثر جاذبية. و عند سؤ اللك احد اصدقاءك المقربين عن رأيه بالتسريحة الجديدة. أجابك بمدى

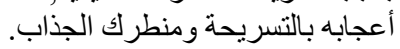

ماهو جوابك له؟

انت تعيش مع احد الاصدقاء في شقة. و اثثاء جلوسكم في الصالة لقضاء بعض الوقت معا. انت سألته ان يعطيك المجلة التي بجانبه. ومن ثم اعطاءك المجلة.

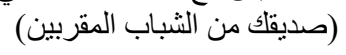




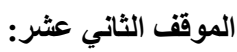

أثناء دخو للك احد مو اقف السيار ات. بادر المشرف على الموقف بأعطاءك بطاقة الدخول. ثم سألثه عن مكان مناسب لإقاف السيارة فأجابك بكل احتر ام.(الرجل اكبر سنناً منك)

ماهو جو ابك له؟

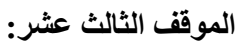

في احد الايام نم دعوتلك من قبل احد اصدقائك الجدد, وبالفعل استجبت و امضيت وقت جمئ جميل برفقت صديقلك و عائلنه بالاضافة الى بعض اصدقاء عائلته, وبعد

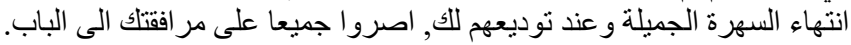

ماهو جو ابك لهم؟

$$
\text { فأهو حصلت على فرصة الرابع عشر: }
$$

$$
\text { الموقف الخامس عشر: }
$$

\section{CHINESE VERSION OF THE DCT}

尊敬的先生和女士:

首先非常感谢您参与这次的问卷调查。这份问卷调查是关于跨文化交际交流的调研。

您所提供的所有信息仅在此次调研中使用。您的回答将被完全保密, 请您放心。在接下来的卷面中, 请您在空 白区域填入相应的信息。

\section{个人信息：}

姓名:

国籍:

语言:

学院:

专业:

年龄:

性别:

\section{问卷指导：}

在接下来需要填写的问卷里, 您将会看到“不同程度的需要表达感谢的场景”。请您想象自己身处在每个不同情 景时的第一反应并填写问卷。在回答每个场景时, 请注意括号里面的提示信息。在对于部分特定场景, 如果在 没有回答的情况下，请您提供为什么没有回答的理由。 


\section{场景 1}

这是一个周五。你打开你的钱包并发现里面仅有两美元。你的好朋友正在工作，并意识到了你的刚才打开钱包 的宕迫情况。这时他听到你自言自语说，“我现在要去银行”。你的这位好朋友立刻问你是否需要钱。你回复他 说，你忘记去银行把钱取出来了。紧接着，你的好朋友说，“我这里有足够的钱，你现在需要多少? ”你回答 说, “你能借给我五美元吗? 我到周一的时候还给你。”你的好朋友回答说, “当然没问题，你确定你只需要五 美元就够了吗? ”你回答说你五美元就够了。然后你的朋友给你借了五美元。（假设你的好朋友是位男性）

你的朋友给你借了五美元后, 这时你会说:

你的朋友给你借了五美元后, 这时你什么都没有说, 原因是 :

\section{场景 2}

你上了一辆公交车, 付了公交车的钱, 并在靠近前排的位置坐下。就在你准备下车的时候, 你猜测这位司机可 能不会停下车等你下车。所以你走到司机身边，要求他停车。（假设这位司机是位年龄较老的人）

你会走到司机身边说:

你会走到司机身边，什么都没有说，原因是：

场景 3

这天是你的生日，你和你的几个朋友在吃晚餐。其中一个朋友给你带了生日礼物。你打开生日礼物，发现礼物 是一件你一直都想要的蓝色毛衣。（假设你的好朋友是位女性）

看到礼物的时候你会说:

看到礼物的时候，你什么都没有说，原因是：

场景 4

你在一家大公司工作, 这家公司的工作通常都非常忙。你给人事部发送了一个邮件, 内容是想要请一天的假。 然后接到副经理的电话, 让你去她办公室。到了副经理办公室, 她让你坐下。这时你感觉自己有点紧张, 因为 你刚在这家公司工作半年。你听到副经理说, “你的工作做的很不错。实际上, 我们对你很满意, 打算要给你 升职。”（假设你的上司是位比你年轻很多的女性）

你听到副经理的话之后, 你会说:

你听到副经理的话之后, 你什么都没说, 原因是:

\section{场景 5}

在超市里, 你要求收营员帮你把买的东西装进袋子里。他帮你装了之后, 准备给下一位顾客结算。你付完你的 钱, 提起你的袋子, 准备离开。（假设这位收营员是位很年老的人） 你在离开的时候, 你会说:

你在离开的时候, 你什么都没说, 原因是:

\section{场景 6}

在一个餐厅里, 你的朋友对你说, “你脸上有点脏东西”。你问脏东西在脸上的哪里。你的朋友指给你脏东西在 的位置。你擦完脸, 问你的朋友, “脏东西擦掉了吗? ”你的朋友说擦掉了。（你的的朋友是位年轻的男性）

在这时, 你会说:

在这时, 你什么都没说, 原因是: 
场景 7

你发现你自己突然急需五百美元。你对你的朋友偶然提到这个情况。你的朋友听到之后立刻提出想要给你借钱 的想法。刚开始你说, “这怎么可以, 我没用想要借你钱的意思, 我不能借你的钱。”你的朋友说, “给你借钱 是我作为朋友应该做的事。”然后你的朋友再次提出要给你借钱的意思。最后你借了你朋友的五百美元。 你借了你朋友的钱之后, 你会说:

你借了你朋友的钱之后，你什么都没说，原因是:

\section{场景 8}

你在另外一个城市学习。你和你的室友都在工作。你下班之后回家晚了, 并且发现你的室友已经做了一部分, 原本你承诺了要去做的家务活。（假设你的室友是位年老的男士）

你看到你的室友做了家务活之后，你会说:

你看到你的室友做了家务活之后，你什么都没说，原因是：

\section{场景 9}

你的朋友建议和你一起出去吃午饭。你说你想去但是你只有两美元。你的朋友说, “别担心, 今天我请客。”你 朋友带你去了一家非常不错的餐厅。这家餐厅的消费要比你通常去的贵很多。你在这家餐厅吃了一顿很不错的 午饭。在你朋友付完钱之后你们准备离开。（假设你的朋友是位比你年长的女性）

在你们准备离开的时候, 你会说:

在你们准备离开的时候, 你什么都没说, 原因是:

场景 10

你刚收到国外大学的录取通知书。其中你的一位好朋友在那所国外大学, 并且告诉你, 她已经为你准备了一场 欢迎会。

你听到这个消息之后，你会说：

你听到这个消息之后，你什么都没有说，原因是：

\section{场景 11}

你刚剪了一个新的发型, 并且这个新发型让你你看起来比以前好看很多。你的朋友看到你的新发型之后, 你问 他的想法。他说, “你剪新发型啦, 看起来不错。”

你听到你朋友的认可之后, 你会说,

你听到你朋友的认可之后，你什么都没有说，原因是：

\section{场景 12}

你和你的一个朋友住在同一间宿舍里。你们坐在卧室里闲聊的时候, 你让你的朋友帮忙递一下靠近他手边的报 纸。然后你的朋友把报纸递给了你。（假设你的朋友是位比你年轻的男性）

当你朋友把报纸递给你的时候，你会说： 
你进入一个停车场。当停车场的管理人员把收费单递给你的时候, 你把钱递给管理人员, 并询问有关是否有空 车位的事宜。（假设停车场的管理人员年龄比你大）

这时候你会说:

这时候你什么都没有说，原因是：

场景 14

你一位新结交的朋友邀请你去他家做客。你和他的家人, 他的几位朋友一起吃了晚餐。晚餐的食物味道很不 错, 你非常享受这顿晚餐。当你快要离开朋友家的时候, 你的朋友把你送到了他家门口。（假设这位朋友和你 的年龄相仿）

这时候, 你会说:

这时候，你什么都没有说，原因是：

\section{场景 15}

今天是你的生日。朋友 $\mathrm{X}$ 给你发送了一条祝福生日快乐的短信。（假设朋友 $\mathrm{X}$ 是位男性）

当你看到祝福短信的时候, 你会说:

当你看到祝福短信的时候，你什么都没有说，原因是：

场景 16

你刚得到一个公司的录取通知书。朋友 $\mathrm{X}$ 知道此消息后, 对你表示了祝贺。（假设朋友 $\mathrm{X}$ 是位年龄比你小的 女性）

这时候你会说:

这时候你什么都没有说, 原因是: 